\title{
Intranasal delivery bypasses the blood-brain barrier to target therapeutic agents to the central nervous system and treat neurodegenerative disease Leah R Hanson ${ }^{1}$ and William H Frey II*1,2
}

\author{
Address: ${ }^{1}$ Alzheimer's Research Center at Regions Hospital, HealthPartners Research Foundation, 640 Jackson Street, St. Paul, Minnesota 55101, \\ USA and ${ }^{2}$ Department of Pharmaceutics, University of Minnesota, 308 Harvard Street S.E., Minneapolis, Minnesota 55455, USA \\ Email: William H Frey* - alzheimr@umn.edu \\ * Corresponding author
}

from 2007 and 2008 Drug Discovery for Neurodegeneration Conference

New York, USA. 5-6 February 2007. Washington, DC, USA. 4-5 February 2008

Published: 10 December 2008

BMC Neuroscience 2008, 9(Suppl 3):S5 doi:10.1186/147I-2202-9-S3-S5

This article is available from: http://www.biomedcentral.com/I47I-2202/9/S3/S5

(C) 2008 Hanson and Frey; licensee BioMed Central Ltd.

This is an open access article distributed under the terms of the Creative Commons Attribution License (http://creativecommons.org/licenses/by/2.0), which permits unrestricted use, distribution, and reproduction in any medium, provided the original work is properly cited.

\begin{abstract}
Intranasal delivery provides a practical, non-invasive method of bypassing the blood-brain barrier (BBB) to deliver therapeutic agents to the brain and spinal cord. This technology allows drugs that do not cross the BBB to be delivered to the central nervous system within minutes. It also directly delivers drugs that do cross the BBB to the brain, eliminating the need for systemic administration and its potential side effects. This is possible because of the unique connections that the olfactory and trigeminal nerves provide between the brain and external environment. Intranasal delivery does not necessarily require any modification to therapeutic agents. A wide variety of therapeutics, including both small molecules and macromolecules, can be targeted to the olfactory system and connected memory areas affected by Alzheimer's disease. Using the intranasal delivery system, researchers have reversed neurodegeneration and rescued memory in a transgenic mouse model of Alzheimer's disease. Intranasal insulin-like growth factor-l, deferoxamine, and erythropoietin have been shown to protect the brain against stroke in animal models. Intranasal delivery has been used to target the neuroprotective peptide NAP to the brain to treat neurodegeneration. Intranasal fibroblast growth factor-2 and epidermal growth factor have been shown to stimulate neurogenesis in adult animals. Intranasal insulin improves memory, attention, and functioning in patients with Alzheimer's disease or mild cognitive impairment, and even improves memory and mood in normal adult humans. This new method of delivery can revolutionize the treatment of Alzheimer's disease, stroke, and other brain disorders.
\end{abstract}

\section{Introduction}

The use of intranasal (IN) administration to target therapeutics to the central nervous system (CNS) has many benefits in the treatment of neurologic disorders. The blood-brain barrier (BBB) restricts the use of numerous therapeutic agents that have been developed to treat memory loss and neurodegeneration because it limits CNS penetration, depending on drug size or charge. 
Although invasive methods of administration (for instance intracerebroventricular) have been used to overcome the $\mathrm{BBB}$, these methods are not practical for use in humans for several reasons, including convenience, safety, and cost. Direct delivery of therapeutics from the nasal cavity into the CNS (IN delivery) bypasses the BBB and provides an alternative to invasive methods of drug administration $[1,2]$. Noninvasive IN delivery targets therapeutics to the CNS, reducing systemic exposure and side effects; this can be advantageous for delivery of many CNS therapeutics, including those that can cross the BBB upon systemic administration. CNS therapeutics do not necessarily need to be modified for IN delivery, and delivery of therapeutics to the CNS is rapid, occurring within minutes. The IN delivery method was first developed by Frey in 1989 [3] for targeting neurotrophic factors (for example, nerve growth factor [NGF] and fibroblast growth factor-2) to the CNS.

\section{Olfactory and trigeminal pathways}

Intranasally administered therapeutics reach the CNS via the olfactory and trigeminal neural pathways. Both the olfactory and trigeminal nerves innervate the nasal cavity, providing a direct connection with the CNS. Direct delivery of therapeutics from the nose to the brain was initially attributed to the olfactory pathway [3-6]. More recently, the contribution made by the trigeminal pathway to IN delivery to the CNS has also been recognized, especially to caudal brain regions and the spinal cord $[7,8]$. Extracellular delivery, rather than axonal transport, is strongly indicated by the short time frame ( $\leq 10$ minutes) observed for IN therapeutics to reach the brain from the nasal mucosa. Possible mechanisms of transport may involve bulk flow and diffusion within perineuronal channels, perivascular spaces, or lymphatic channels directly connected to brain tissue or cerebrospinal fluid [9].

\section{Intranasal delivery targets therapeutics to the central nervous system}

IN delivery has been used to target a wide variety of therapeutics to the CNS. For example, the following classes of therapeutics have successfully been intranasally delivered to the CNS: neurotrophins (NGF [5] and insulin-like growth factor [IGF]-1 [7]); neuropeptides (hypocretin-1 [10] and exendin [11]); cytokines (interferon $\beta-1 \mathrm{~b}[8]$ and erythropoietin [12]); polynucleotides (DNA plasmids [13] and genes [14]); and small molecules (chemotherapeutics [15] and carbamazepine [16]). IN delivery works best for potent therapeutics that are active in the nanomolar range [1]. Even therapeutics that are substrates for the P-glycoprotein efflux transporter, which is known to operate in the nasal epithelium, have been reported to reach the CNS in effective concentrations [17].

\section{Intranasal neurotrophins for the treatment of neurodegeneration}

Although the ability of neurotrophins to protect and promote the growth of new neurons makes them desirable candidates for the treatment of neurodegenerative disease, the inability of neurotrophins to cross the BBB efficiently, and the impracticality of invasive injection methods, have prevented their use. Growing evidence suggests that IN administration of neurotrophins provides a noninvasive way to target neurotrophins to the CNS to treat neurodegeneration. In a mouse model of Alzheimer's disease, IN administered NGF both reduced neurodegeneration and improved performance in memory tasks $[18,19]$. In a rat model of stroke, IN IGF-I reduced brain damage and neurologic deficits [20]. In addition, cerebral neurogenesis was induced in the subventricular zone of adult mice after IN administration of FGF-2 [21]. IN activity dependent neurotrophic factor, as well as its active peptide fragment NAP, have been shown to reduce neurodegeneration, tau pathology, amyloid accumulation, and memory loss in mouse models of Alzheimer's disease [22-25]. IN NAP is now being tested in phase II clinical trials as a potential treatment for Alzheimer's disease and mild cognitive impairment.

\section{Memory is improved by intranasal insulin treatment}

IN insulin improves memory in normal adults and patients with Alzheimer's disease without altering blood glucose. Energy metabolism in the CNS is dependent upon glucose uptake and is regulated by insulin in key brain regions. It has long been known that glucose uptake and utilization are deficient in patients with Alzheimer's disease [26]. Recently, the gene expression levels of insulin, IGF-1, and their receptors were shown to be markedly reduced in the brains of patients with Alzheimer's disease [27]. Consequently, ability to deliver insulin to the CNS without altering blood glucose could provide an effective means to improve glucose uptake and utilization, and reduce cognitive deficits in patients with memory disorders.

Using the IN delivery method to target insulin to the CNS originally developed by Frey [28], Born and coworkers [29] demonstrated that cerebrospinal fluid insulin levels significantly increased after treatment of normal adults with insulin, with no change in blood levels of insulin. In normal adults, IN treatment with insulin for 8 weeks improved memory (delayed recall of words) and mood at doses that did not alter blood levels of insulin or glucose [30]. In addition, IN administration of a rapidly acting form of insulin that forms hexamers and is more rapidly absorbed, insulin aspart, improved memory in normal adults significantly more than did regular insulin [31]. In Alzheimer's patients, a single IN treatment acutely improved verbal memory (total story recall and total word 
list recall) at doses that did not alter blood levels of insulin or glucose [32]. The benefit of IN insulin treatment was seen primarily for Alzheimer's patients without the apolipoprotein $\mathrm{E} \varepsilon 4$ allele. Longer treatment with IN insulin (21 days) enhanced memory, attention, and functioning compared with placebo in patients with either early stage Alzheimer's disease or mild cognitive impairment $[33,34]$.

\section{Conclusion}

IN delivery is a noninvasive method that bypasses the BBB and targets drugs to the CNS, reducing systemic exposure and side effects. This novel method has already been used successfully to improve memory in both normal adults and patients with Alzheimer's disease. IN delivery could revolutionize the way we treat Alzheimer's disease and other neurodegenerative disorders.

\section{List of abbreviations used}

BBB: blood-brain barrier; CNS: central nervous system; IN: intranasal; NGF: nerve growth factor.

\section{Competing interests}

WHF holds intellectual property related to IN delivery of therapeutics. LRH and WHF are inventors on patents related to IN delivery of therapeutics.

\section{Acknowledgements}

This article has been published as part of BMC Neuroscience Volume 9 Supplement 3, 2008: Proceedings of the 2007 and 2008 Drug Discovery for Neurodegeneration Conference. The full contents of the supplement are available online at http://www.biomedcentral.com/I47I-2202/9? issue=S3.

\section{References}

I. Dhanda DS, Frey WH 2nd, Leopold D, Kompella UB: Approaches for drug deposition in the human olfactory epithelium. Drug Delivery Technol 2005, 5:64-72.

2. Frey WH 2nd: Bypassing the blood-brain barrier to delivery therapeutic agents to the brain and spinal cord. Drug Delivery Technol 2002, 5:46-49.

3. Frey WH 2nd: (WO//99//007947) Neurologic Agents for Nasal Administration to the Brain (priority date 5./2.89) 1991 [http:// www.wipo.inpctdb/en/

wo.jsp?wo $=|991007947 \&| \mathrm{A}=\mathrm{WO} 1991007947 \& D I S$ PLAY $=$ CLAIMS $]$ Geneva, Switzerland: World Intellectual Property Organization

4. Thorne RG, Emory CR, Ala TA, Frey WH 2nd: Quantitative assessment of protein transport to the rat olfactory bulb following intranasal administration: implications for drug delivery. Brain Res 1995, 692:278-282.

5. Chen X-Q, Fawcett JR, Rahman Y-E, Ala TA, Frey WH 2nd: Delivery of nerve growth factor to the brain via the olfactory pathway. A Alzheimer's Dis 1998, I:35-44.

6. Frey WH 2nd, Liu J, Chen X, Thorne RG, Fawcett JR, Ala TA, Rahman Y-E: Delivery of I25I-NGF to the brain via the olfactory route. Drug Deliv 1997, 4:87-92.

7. Thorne RG, Pronk GJ, Padmanabhan V, Frey WH 2nd: Delivery of insulin-like growth factor-I to the rat brain and spinal cord along olfactory and trigeminal pathways following intranasal administration. Neuroscience 2004, I 27:48|-496.

8. Ross TM, Martinez PM, Renner JC, Thorne RG, Hanson LR, Frey WH 2nd: Intranasal administration of interferon beta bypasses the blood-brain barrier to target the central nervous system and cervical lymph nodes: a non-invasive treatment strategy for multiple sclerosis. J Neuroimmunol 2004, I 5 I:66-77.
9. Thorne RG, Frey WH 2nd: Delivery of neurotrophic factors to the central nervous system: pharmacokinetic considerations. Clin Pharmacokinet 200I, 40:907-946.

10. Hanson LR, Martinez PM, Taheri S, Kamsheh L, Mignot E, Frey WH 2nd: Intranasal administration of hypocretin I (orexin A) bypasses the blood-brain barrier \& targets the brain: a new strategy for the treatment of narcolepsy. Drug Delivery Technol 2004, 4:65-7I.

II. Banks WA, During MJ, Niehoff ML: Brain uptake of the glucagonlike peptide-I antagonist exendin(9-39) after intranasal administration. J Pharmacol Exp Ther 2004, 309:469-475.

12. Yu YP, Xu QQ, Zhang Q, Zhang WP, Zhang LH, Wei EQ: Intranasal recombinant human erythropoietin protects rats against focal cerebral ischemia. Neurosci Lett 2005, 387:5-10.

13. Han IK, Kim MY, Byun HM, Hwang TS, Kim JM, Hwang KW, Park TG, Jung WW, Chun T, Jeong G], Oh YK: Enhanced brain targeting efficiency of intranasally administered plasmid DNA: an alternative route for brain gene therapy. J Mol Med 2006, 85:75-83.

14. Draghia R, Caillaud C, Manicom R, Pavirani A, Kahn A, Poenaru L: Gene delivery into the central nervous system by nasal instillation in rats. Gene Ther 1995, 2:418-423.

15. Wang D, Gao Y, Yun L: Study on brain targeting of raltitrexed following intranasal administration in rats. Cancer Chemother Pharmacol 2005, 57:97-104.

16. Barakat NS, Omar SA, Ahmed AA: Carbamazepine uptake into rat brain following intra-olfactory transport. J Pharm Pharmacol 2006, 58:63-72.

17. Graff CL, Pollack GM: P-glycoprotein attenuates brain uptake of substrates after nasal instillation. Pharm Res 2003, 20:1225-1230.

18. Capsoni S, Giannotta S, Cattaneo A: Nerve growth factor and galantamine ameliorate early signs of neurodegeneration in anti-nerve growth factor mice. Proc Natl Acad Sci USA 2002, 99: $12432-12437$.

19. de Rosa R, Garcia AA, Braschi C, Capsoni S, Maffei L, Berardi N, Cattaneo A: Intranasal administration of nerve growth factor (NGF) rescues recognition memory deficits in ADII antiNGF transgenic mice. Proc Natl Acad Sci USA 2005, 102:38II-3816.

20. Liu XF, Fawcett JR, Hanson LR, Frey WH 2nd: The window of opportunity for treatment of focal cerebral ischemic damage with noninvasive intranasal insulin-like growth factor-I in rats. J Stroke Cerebrovasc Dis 2004, 13:16-23.

21. Jin K, Xie L, Childs J, Sun Y, Mao XO, Logvinova A, Greenberg DA: Cerebral neurogenesis is induced by intranasal administration of growth factors. Ann Neurol 2003, 53:405-409.

22. Matsuoka Y, Jouroukhin Y, Gray AJ, Ma L, Hirata-Fukae C, Li HF, Feng L, Lecanu L, Walker BR, Planel E, Arancio O, Gozes I, Aisen PS: A neuronal microtubule-interacting agent, NAPVSIPQ, reduces tau pathology and enhances cognitive function in a mouse model of Alzheimer's disease. J Pharmacol Exp Ther 2008, 325: I 46-153.

23. Matsuoka Y, Gray AJ, Hirata-Fukae C, Minami SS, Waterhouse EG, Mattson MP, LaFerla FM, Gozes I, Aisen PS: Intranasal NAP administration reduces accumulation of amyloid peptide and tau hyperphosphorylation in a transgenic mouse model of Alzheimer's disease at early pathological stage. J Mol Neurosci 2007, 31:165-I70.

24. Visochek L, Steingart RA, Vulih-Shultzman I, Klein R, Priel E, Gozes I, Cohen-Armon M: PolyADP-ribosylation is involved in neurotrophic activity. J Neurosci 2005, 25:7420-7428.

25. Gozes I, Giladi E, Pinhasov A, Bardea A, Brenneman DE: Activitydependent neurotrophic factor: intranasal administration of femtomolar-acting peptides improve performance in a water maze. J Pharmacol Exp Ther 2000, 293:1091-1098.

26. de Leon MJ, Ferris SH, George AE, Christman DR, Fowler JS, Gentes C, Reisberg B, Gee B, Emmerich M, Yonekura Y, Brodie J, Kricheff II, Wolf AP: Positron emission tomographic studies of aging and Alzheimer disease. AJNR Am / Neuroradiol 1983, 4:568-57I.

27. Steen E, Terry BM, Rivera EJ, Cannon JL, Neely TR, Tavares R, Xu XJ, Wands JR, de la Monte SM: Impaired insulin and insulin-like growth factor expression and signaling mechanisms in Alzheimer's disease: is this type 3 diabetes? J Alzheimers Dis 2005, 7:63-80. 
28. Frey WH 2nd: US Patent 63 / 3093: Method for Administering Insulin to the Brain 200I [http://patft.uspto.gov/]. US Patent and Trademark Office

29. Born J, Lange T, Kern W, McGregor GP, Bickel U, Fehm HL: Sniffing neuropeptides: a transnasal approach to the human brain. Nat. Neurosci 2002, 5:514-5I6.

30. Benedict C, Hallschmid M, Hatke A, Schultes B, Fehm HL, Born J, Kern W: Intranasal insulin improves memory in humans. Psychoneuroendocrinology 2004, 29: 1326-1334.

31. Benedict C, Hallschmid M, Schmitz K, Schultes B, Ratter F, Fehm HL, Born J, Kern W: Intranasal insulin improves memory in humans: superiority of insulin aspart. Neuropsychopharmacology 2007, 32:239-243.

32. Reger MA, Watson GS, Frey WH 2nd, Baker LD, Cholerton B, Keeling ML, Belongia DA, Fishel MA, Plymate SR, Schellenberg GD, Cherrier MM, Craft $S$ : Effects of intranasal insulin on cognition in memory-impaired older adults: modulation by APOE genotype. Neurobiol Aging 2006, 27:45I-458.

33. Reger MA, Watson GS, Green PS, Wilkinson CW, Baker LD, Cholerton B, Fishel MA, Plymate SR, Breitner JC, DeGroodt W, Mehta P, Craft $\mathrm{S}$ : Intranasal insulin improves cognition and modulates beta-amyloid in early AD. Neurology 2008, 70:440-448.

34. Reger MA, Watson GS, Green PS, Baker LD, Cholerton B, Fishel MA, Plymate SR, Cherrier MM, Schellenberg GD, Frey WH 2nd, Craft S: Intranasal insulin administration dose-dependently modulates verbal memory and plasma amyloid-beta in memoryimpaired older adults. J Alzheimers Dis 2008, 13:323-331.

Publish with Bio Med Central and every scientist can read your work free of charge

"BioMed Central will be the most significant development for disseminating the results of biomedical research in our lifetime. "

Sir Paul Nurse, Cancer Research UK

Your research papers will be:

- available free of charge to the entire biomedical community

- peer reviewed and published immediately upon acceptance

- cited in PubMed and archived on PubMed Central

- yours - you keep the copyright

Submit your manuscript here:

http://www.biomedcentral.com/info/publishing_adv.asp
BioMedcentral 